\title{
Long-Term Results in Transcanalicular Laser and External Dacryocystorhinostomy
}

\author{
(1) Halil Ibrahim Yener, (1) Muammer Ozcimen \\ Department of Ophthalmology, Health Science University, Konya Research Hospital, Konya, Turkey
}

\begin{abstract}
Objectives: This study was an examination of the long-term results of transcanalicular laser (TCL) and external (EX) dacryocystorhinostomy (DCR).

Methods: Patients who had undergone TCL-DCR or EX-DCR between 2009 and 2013 were invited for long-term follow-up in 2019. All of the patients who responded had an ophthalmic examination and were assessed using lacrimal irrigation. An intranasal evaluation was performed when the irrigation test had non-patent results. TCL procedures were performed with a diode laser $(980 \mathrm{~nm})$. Ostium cleansing with a suction unit and a nasal endoscope was performed in the first week. In EX-DCR procedures, an anterior flap was created and tented to the orbicularis oculi muscle. A silicon tube was implanted in both methods and removed at 4-6 months.

Results: A total of 74 EX-DCR patients were assessed. The lacrimal irrigation test was negative in 5 cases. The functional success rate was $93.2 \%$ with a follow-up of 8 years. A total of 63 patients who had undergone TCL-DCR were evaluated and the irrigation test was negative in 9 patients. The functional success rate was $85.7 \%$ with a follow-up of 7 years. The difference in the success rate was statistically insignificant with a $P$ value of 0.09 .

Conclusion: The long-term success rates of both EX-DCR and TCL-DCR were high.

Keywords: Dacryocystorhinostomy, external, laser, nasolacrimal, transcanalicular.
\end{abstract}

\section{Introduction}

Dacryocystorhinostomy (DCR) is the most commonly used method to treat nasolacrimal duct obstruction. External (EX)-DCR has been accepted as the standard therapy for over a century. With the development of endoscopic imaging, successful results have now also been achieved with transcanalicular laser (TCL) endoscopic methods (I, 2).

Eloy et al. (3) performed the first TCL-DCR in 2000, and reported successful results in $17(58 \%)$ of 29 patients. Advantages of the TCL-DCR method are the absence of a skin incision, a shorter surgical time, and less orbital morbidity $(2,3)$. The cauterization effect of the laser also allows for surgery with less bleeding than the external method (4). Although surgical procedures using an endoscope and a laser provide advantages, the expense of the surgical equipment is a disadvantage.

DCR with various techniques is generally a successful surgery; however, the ostium may close over time. Failed cases are typically related to nasal septal pathology or obstruction of the ostium with fibrotic tissue. In the literature, although results of periods of less than I year have frequently been studied, data of long-term success are limited.

The objective of this study was to investigate the longterm outcomes of both EX-DCR and TCL-DCR procedures.

Address for correspondence: Halil Ibrahim Yener, MD. Saglik Bilimleri Universitesi, Konya Arastirma Hastanesi, Goz Hastaliklari Anabilim Dali, Konya, Turkey

Phone: +90 5322483383 E-mail: halilibrahimyener@hotmail.com

Submitted Date: November 23, 2019 Accepted Date: December 22, 2019 Available Online Date: February 17, 2020

${ }^{\circ}$ Copyright 2020 by Beyoglu Eye Training and Research Hospital - Available online at www.beyoglueye.com OPEN ACCESS This work is licensed under a Creative Commons Attribution-NonCommercial 4.0 International License. 


\section{Methods}

In this study, patients who underwent EX-DCR or TCLDCR with the same surgeon at a single center in 2009-20I3 were investigated. The EX-DCR group underwent surgery in 2009-20II and the TCL-DCR group surgeries were performed in 2010-2013. All of the study patients had a distal nasolacrimal duct obstruction. Patients with canalicular-punctal pathology, ectropion, or entropion were not included in the study.

All of the patients in both groups were contacted by telephone in 2019 for re-examination. The participating patients had a complete ophthalmological examination and lacrimal irrigation was performed. Nasal structures were evaluated with a nasal endoscope in patients with a non-patent ostium based on the lacrimal irrigation test. Functional success was defined as anatomically patent rhinostomy and the absence of epiphora.

In the TCL-DCR cases, all of the surgeries were performed with local anesthesia and an infratrochlear and infraorbital nerve block. Topical anesthesia was applied to the nose and the eye. Canalicular dilatation was performed and the laser probe was introduced to the medial part of the lacrimal sac. A diode laser $(980 \mathrm{~nm})$ was advanced from the sac medial to the medial orbital wall and exited the nasal mucosa. Endoscopic laser imaging of the nasal opening was enlarged to $6 \times 10 \mathrm{~mm}$, followed by bicanalicular silicone tube intubation. In the first week, debris in the nasal ostium was removed using a suction unit and an endoscope.

In the EX-DCR cases, local anesthesia was performed as in the transcanalicular method. After a $20-\mathrm{mm}$ skin incision was made $10-12 \mathrm{~mm}$ from the medial canthal region, the orbicularis tissue and the anterior crus of the medial canthal ligament were separated in order to reach the periosteum. A periosteal incision was made and the lacrimal crest was exposed. An aperture was formed with the help of a periosteal elevator and the aperture was expanded to $15 \times 15 \mathrm{~mm}$ with a bone punch. The nasal mucosa was exposed and a single anterior lacrimal sac flap was formed. A nasal mucosa flap was created to fit this flap. The flaps were ligated with absorbable sutures after passage through both canaliculi. The flaps were suspended to the orbicularis muscle with sutures from both the nasal mucosa and the sac, to prevent collapse.

A bicanalicular silicone tube was used in all surgeries in both methods and removed after 4-6 months.

Informed consent was obtained from all of the study patients and the Helsinki Declaration guidelines were observed. Approval was granted by the Ethics Committee of Selcuk University Education and Research Hospital.

A chi-square test was used for the statistical analysis. A p value of $<0.05$ was considered significant.

\section{Results}

The mean follow-up time was 90.2 months (min-max: 85108 months) in the EX-DCR group, and 73.2 months (minmax: 69-87 months) in the TCL-DCR group.

A total of 118 patients underwent EX-DCR, and 74 patients responded to the request for a long-term follow-up examination. The mean age of the patients evaluated in this group was $54.7 \pm 9$.I years (min-max: 30-79 years). Five patients complained of tearing. The lacrimal irrigation test was negative in all 5 patients. The 8-year functional success rate was $93.2 \%$.

Among 123 patients who underwent TCL-DCR, 63 patients were examined for the study. The mean age of the patients evaluated was $57.8 \pm 8.4$ years (min-max: $46-80$ years). Nine patients reported tearing. The lacrimal irrigation test was negative in all 9 patients. The 7-year functional success rate was $85.7 \%$.

Although the success rate in the EX-DCR group was higher than that of the TCL-DCR group, the difference was not statistically significant $(p=0.09)$

When the patients in both groups with a negative irrigation test $(n=13)$ were evaluated with an endoscope, in all cases, fibrotic tissue was the cause of the ostium closure. In 7 of these cases, synechia was present between the lateral nasal mucosa and the concha, while in 6 cases, synechia was observed between the lateral nasal mucosa and the septum.

\section{Discussion}

Failure in both EX-DCR and TCL-DCR procedures is generally due to the closure of the created ostium by granulation tissue or synechia between the middle turbinate and the septum. Some studies have examined the use of additional endonasal intervention or antifibrotic agents to prevent the development of granulation tissue and synechia $(5,6)$.

In the literature, the success rate of EX-DCR is $86-95.4 \%$ in the first year, $92.4-98.9 \%$ in the second year, and $71-97 \%$ in the third and fourth years (Table I) (7-18).

There are very few studies reporting results for 5 years or more. In a study by Alnawiesh et al., (I) the success rate of EX-DCR was reported to be $83 \%$ with a 5 -year follow-up. Erdol et al. (19) reported on 387 patients with 69 months of follow-up. The success rate of $98.4 \%$ was one of the highest in the literature. They noted that reasons for the high success rate included only minor wound complications due to the advantage of the direct visualization of the operation site, adequate osteotomy size, and a smooth anastomosis between the nasal mucosa and lacrimal sac. Mansour et al. (16) reported a declining success rate in EX-DCR patients of $89 \%$ in the first year, $79 \%$ in $2-3$ years, and $71 \%$ in $4-5$ years. In a study by Heichel et al. (18) with 
Table I. Studies of external and transcanalicular dacryocystorhinostomy

\section{External}

dacryocystorhinostomy

\begin{tabular}{|c|c|c|c|c|c|}
\hline & $\begin{array}{l}\text { Duration } \\
\text { (months) }\end{array}$ & Success (\%) & & $\begin{array}{l}\text { Duration } \\
\text { (months) }\end{array}$ & Success (\%) \\
\hline Yeniad & 3 & 89.4 & Yeniad & 3 & 84.2 \\
\hline Mourya & 7 & 95.4 & Kaynak & 3 & 85.4 \\
\hline Derya & 12 & 86 & Mourya & 7 & 90.1 \\
\hline Hartikainen & 12 & 91 & Drnovsek & 12 & 83.3 \\
\hline Deka & 13 & 98.9 & Kaynak & 12 & 63.3 \\
\hline Kazanci & 16 & 92.4 & Yildirim & 18 & 84.4 \\
\hline Warren & 32 & 93 & Alañón & 20 & 90.7 \\
\hline Yuksel & 33 & 97 & Kaynak & 24 & 60.3 \\
\hline Heichel & 48 & 94.4 & Plaza & 36 & 88 \\
\hline Mansour & 55 & 71 & Nuhoglu & 42 & 95.2 \\
\hline Alnawiesh & 60 & 83 & Dogan & 60 & 75.0 \\
\hline
\end{tabular}

a mean follow-up of 4 years (range: I-I 2 years), a $94.4 \%$ success rate was reported.

This study examined the long-term results of 2 previous DCR studies $(20,21)$. In the EX-DCR study, the 6-month success was $97.4 \%$, and it declined to $93.2 \%$ in the 8 th year. The eighth year success rate, however, was still high (20). Tenting the anterior anastomosis to the orbicularis muscle may have been the primary reason. The use of a silicone tube and a $15 x \mid 5$ osteotomy may also be factors in the high success rate.

The success rate of TCL-DCR in the literature varies between $63.3 \%-90.1 \%$ in the first year, $60.3 \%-90.7 \%$ in the second year, and $88 \%-95.2 \%$ in the third and fourth years (Table I) $(2,4,7,8,22-26)$. There are few studies with longterm follow-up of TCL-DCR. Yildirim et al. (25) reported an $84.4 \%$ success rate with a follow-up of 18 months. They recommended bicanalicular silicone tube intubation to increase success. To our knowledge, there is only I study with a follow up of 5 years. Dogan et al., (27) reported on a follow-up of 60 months with a $75 \%$ success rate, which was lower than that of other studies in the literature. The authors hypothesized that the longer follow-up time contributed to the lower success rate. Kaynak et al. (24) reported a success rate of $60.3 \%$ at 2 years of follow-up. They reported that the lower success rate was related to not thoroughly removing the debris.

In the previously mentioned TCL-DCR study (20), the 6-month success rate was $95.1 \%$. The current findings were a seventh year success rate in the TCL-DCR patients of $85.7 \%$. The long-term success rate is still high in comparison with the results of study of Dogan et al. (27). In our study, ostium cleaning performed in the postoperative first week and bicanalicular silicone tube implantation may have been important factors leading to a higher success rate.

\section{Conclusion}

In conclusion, the number of patients in this study is comparable to that of the studies in the literature. The surgeries were performed by a single surgeon and long-term results were assessed. Both EX-DCR and TCL-DCR demonstrated high long-term success.

\section{Disclosures}

Ethics Committee Approval: The Ethics Committee of Selcuk University Training and Research Hospital provided the ethics committee approval for this study (20/4/95).

Peer-review: Externally peer-reviewed.

Conflict of Interest: None declared.

Authorship Contributions: Involved in design and conduct of the study (HIY); preparation and review of the study (HIY, MO); data collection (MO); and statistical analysis (HIY).

\section{References}

I. Dalgic A, Ceylan ME, Çelik Ç, Aliyeva A, Aksoy GY, Edizer DT. Outcomes of endoscopic powered revision dacryocystorhinostomy. J Craniofac Surg 2018;29:1960-2. [CrossRef]

2. Alañón Fernández FJ, Alañón Fernández MA, Martínez Fernán$\operatorname{dez} A$, Cárdenas Lara M. Transcanalicular dacryocystorhinostomy technique using diode laser. [Article in Spanish] Arch Soc Esp Oftalmol.2004;79:325-30. [CrossRef] 
3. Eloy P, Trussart C, Jouzdani E, Collet S, Rombaux P, Bertrand B. Transcanalicular diode laser assisted dacryocystorhinostomy. Acta Otorhinolaryngol Belg 2000;54:157-63.

4. Plaza G, Beteré F, Nogueira A. Transcanalicular dacryocystorhinostomy with diode laser: long-term results. Ophthalmic Plast Reconstr Surg 2007;23:179-82. [CrossRef]

5. Basmak H, Caklı H, Sahin A, Gursoy H, Ozer A, Altun E, et al. Comparison of endocanalicular laser dacryocystorhinostomy with and without endonasal procedures. Graefes Arch Clin Exp Ophthalmol 20I I;249:737-43. [CrossRef]

6. Henson RD, Henson RG Jr, Cruz HL Jr, Camara JG. Use of the diode laser with intraoperative mitomycin $\mathrm{C}$ in endocanalicular laser dacryocystorhinostomy. Ophthalmic Plast Reconstr Surg 2007;23:134-7. [CrossRef]

7. Yeniad B, Uludag G, Kozer-Bilgin L. Assessment of patient satisfaction following external versus transcanalicular dacryocystorhinostomy with a diode laser and evaluation if change in quality of life after simultaneous bilateral surgery in patients with bilateral nasolacrimal duct obstruction. Curr Eye Res 20I2;37:286-92. [CrossRef]

8. Mourya D, Rijal RK. Transcanalicular laser-assisted dacryocystorhinostomy with diode laser. Orbit 2017;36:370-4. [CrossRef]

9. Derya K, Demirel S, Doganay S, Orman G, Cumurcu T, Gunduz A. Endoscopic transcanalicular diode laser dacryocystorhinostomy: Is it an alternative method to conventional external dacryocystorhinostomy? Ophthalmic Plast Reconstr Surg 2013;29:15-7. [CrossRef]

10. Hartikainen J, Grenman R, Puukka P, Seppä H. Prospective randomized comparison of external dacryocystorhinostomy and endonasal laser dacryocystorhinostomy. Ophthalmology 1998; 105:1 106-13. [CrossRef]

II. Moore WM, Bentley CR, Olver JM. Functional and anatomic results after two types of endoscopic endonasal dacryocystorhinostomy: surgical and holmium laser. Ophthalmology 2002;109:1575-82. [CrossRef]

12. Warren JF, Seiff SR, Kavanagh MC. Long-term results of external dacryocystorhinostomy. Ophthalmic Surg Lasers Imaging 2005;36:446-50. [CrossRef]

13. Deka A, Saikia SP, Bhuyan SK. Combined posterior flap and anterior suspended flap dacryocystorhinostomy: A modification of external dacryocystorhinostomy. Oman J Ophthalmol 2010;3:18-20. [CrossRef]

14. Kazancı B, Ersan I, Özek D, Gencer B. External dacryocystorhinostomy: Anastomosis by single or double flap. Dicle Medical J 2013;40:60I-4. [CrossRef]

15. Yuksel D, Kosker M, Akoz I, Simsek S. Long-term results of simultaneous bilateral external dacryocystorhinostomy in cases with bilateral dacryostenosis. Semin Ophthalmol 2015;30:20-4.

16. Mansour K, Sere M, Oey AG, Bruin KJ, Blanksma LJ. Long term patient satisfaction of external dacryocystorhinostomy. Ophthalmologica 2005;219:97-100. [CrossRef]

17. Alnawaiseh M, Mihailovic N, Wieneke AC, Prokosch V, Rosentreter A, Merté RL, et al. Long-term outcomes of external dacryocystorhinostomy in the age of transcanalicular microendoscopic techniques. J Ophthalmol 2016;2016:5918457. [CrossRef]

18. Heichel J, Hassan T, Bredehorn-Mayr T, Wienke A, Struck HG. External dacryocystorhinostomy analysis of patient material of the university hospital halle from 2000 to 201 I. [Article in German] Klin Monbl Augenheilkd 2016;233:29-37. [CrossRef]

19. Erdöl H, Akyol N, Imamoglu HI, Sözen E. Long-term follow-up of external dacryocystorhinostomy and the factors affecting its success. Orbit 2005;24:99-102. [CrossRef]

20. Caglar C, Yener HI, Gul A, Ozcimen M. The modified technique of external dacryocystorhinostomy in the management of complicated nasolacrimal duct obstruction. J Craniofac Surg 2016;27:416-9. [CrossRef]

21. Yener HI, Gul A, Caglar C, Ozcimen M. The effectiveness of postoperative early ostium cleaning in transcanalicular diode laser-assisted dacryocystorhinostomy. Ophthalmic Plast Reconstr Surg 20 I 4;30:476-9. [CrossRef]

22. Drnovsek-Olup B, Beltram M. Transcanalicular diode laser assisted dacryocystorhinostomy. Indian J Ophthalmol 2010;58:2 13-7. [CrossRef]

23. Nuhoglu F, Gurbuz B, Eltutar K. Long-term outcomes after transcanalicular laser dacryocystorhinostomy. Acta Otorhinolaryngol Ital 2012;32:258-62.

24. Kaynak P, Ozturker C, Yazgan S, Karabulut GO, Akar S, Demirok $A$, et al. Transcanalicular diode laser assisted dacryocystorhinostomy in primary acquired nasolacrimal duct obstruction: 2-year follow up. Ophthalmic Plast Reconstr Surg 20। 4;30:28-33. [CrossRef]

25. Yildirim Y, Kar T, Topal T, Cesmeci E, Kaya A, Colakoglu K, et al. Comparison of transcanalicular multidiode laser dacryocystorhinostomy with and without silicon tube intubation. J Ophthalmol 2016;2016:6719529. [CrossRef]

26. Yazgan S, Çelik T, Koç H, Doğan M. Effectiveness of transcanalicular diode laser-assisted dacryocystorhinostomy in cases with failure after at least two external dacryocystorhinostomy: two-year results. Turkiye Klinikleri J Ophthalmol 2017;26:175-80. [CrossRef]

27. Doğan M, Alizada A, Yavaş GF, Kahveci OK, Bakan O. Laser-assisted dacryocystorhinostomy in nasolacrimal duct obstruction: 5-year follow-up. Int J Ophthalmol 2018;11:1616-20. 